\title{
Five egg-laying queens in a single colony of brazilian stingless bees (Melipona scutellaris Latreille)
}

Carlos Alfredo Lopes de CARVALHO ${ }^{1}$, Bruno de Almeida SOUZA², Carleandro de Souza DIAS ${ }^{3}$, Rogério Marcos de Oliveira ALVES ${ }^{4}$, Alex Fábio de Lima MELO5, Ana Cristina Fermino SOARES 6 , Gislene Almeida CARVALHO-ZILSE ${ }^{7}$

\section{ABSTRACT}

Polygyny, characterized by the presence of several egg-laying queens, is considered as a temporary colony status. In stingless bees it is rarely observed. This paper reports the first case of natural polygyny in Melipona scutellaris colony, with five egglaying queens.

KEYWORDS: Meliponini, “uruçu” stingless bee, physogastric queens

\section{Presença de cinco rainhas fisogástricas em colônia de abelha sem ferrão (Melipona scutellaris Latreille)}

\section{RESUMO}

Poliginia, caracterizada pela presença de mais de uma rainha poedeira, é considerada como uma condição temporária em colônias. Em abelhas sem ferrão isso é raramente observado. Este artigo registra o primeiro caso de poliginia natural em colônia de Melipona scutellaris, com cinco rainhas poedeiras.

PALAVRAS-CHAVE: Meliponini, abelha uruçu, rainhas fisogástricas

${ }^{1}$ Universidade Federal do Recôncavo da Bahia, E-mail: calfredo@ufrb.edu.br

2 Empresa Brasileira de Pesquisa Agropecuária, E-mail: bruno@cpamn.embrapa.br

${ }^{3}$ Empresa Baiana de Desenvolmento Agrícola, E-mail: carleandro@gmail.com

${ }^{4}$ Instituto Federal Baiano, E-mail: eiratama@gmail.com

${ }^{5}$ Centro de Treinamento de Líderes de Ruy Barbosa, E-mail: alex_fabio1@yahoo.com.br

${ }^{6}$ Universidade Federal do Recôncavo da Bahia, E-mail: acsoares@ufrb.edu.br

${ }^{7}$ Instituto Nacional de Pesquisas da Amazônia. E-mail: gislene@inpa.gov.br 


\section{INTRODUCTION}

The stingless bees form a diverse group of several hundred species, mainly in tropical areas (Silveira et al. 2002; Michener 2007; Camargo and Pedro 2008). Their colonies have a high level of social organization, almost always with a single queen (Peters et al. 1999), which is a female morphologically differentiated and specialized in egg laying (Michener 1974; Koedam et al. 2007). Studies on stingless bees' reproductive systems have been conducted with few species and remain unknown for the majority. However, such knowledge is important for the development of improved hive handling and operation methods (Carvalho-Zilse and Kerr 2004; Cortopassi-Laurino et al. 2006).

Polygyny, characterized by the presence of several egglaying queens, is considered a temporary colony status (Velthuis et al. 2006). In stingless bees, polygyny is rarely observed, and evidence has been reported only for Plebeia (Silva 1972; Witter and Wittmann 1997) and Melipona, the latter with reports of up to three egg-laying queens in M. quadrifasciata (Cappas-e-Souza 2000) and persistent facultative polygyny has been repeatedly noted in $M$. bicolor (Bego 1983; Velthuis et al. 2001, 2006).

Melipona scutellaris Latreille is a stingless bee species from Northeastern Brazil, which is well-known for its importance in regional meliponiculture for honey production (Carvalho $e t$ al. 2003). This paper reports the first case of natural polygyny in $M$. scutellaris colony, with five egg-laying queens.

\section{MATERIAL AND METHODS}

A colony located in the County of Ruy Barbosa, State of Bahia, Brazil (12¹7’03" South; 40²9'40” West; Altitude: 368 meters), kept in a managed INPA type hive (INPA: Instituto Nacional de Pesquisas da Amazônia), was divided in March of 2008 (Fig. 1). Thirty days after colony division, the presence of five physogastric queens was observed in the daughter colony (Fig. 2). In May of 2008, the colony was transferred to the meliponary of the "Research Group Insecta", located at an experimental station of the Federal University of Recôncavo of Bahia, in the campus of Cruz das Almas, State of Bahia, Brazil.

A glass cover was placed over the hive to allow observation and video recording of queens and workers. The colony was fed with a sugar solution (50\% sucrose and 50\% water), and also with pollen and honey from other stingless bee colonies, using an artificial feeder. Behavioral observations on queen, cell provisioning, and oviposition were conducted in the period from May to July of 2008.

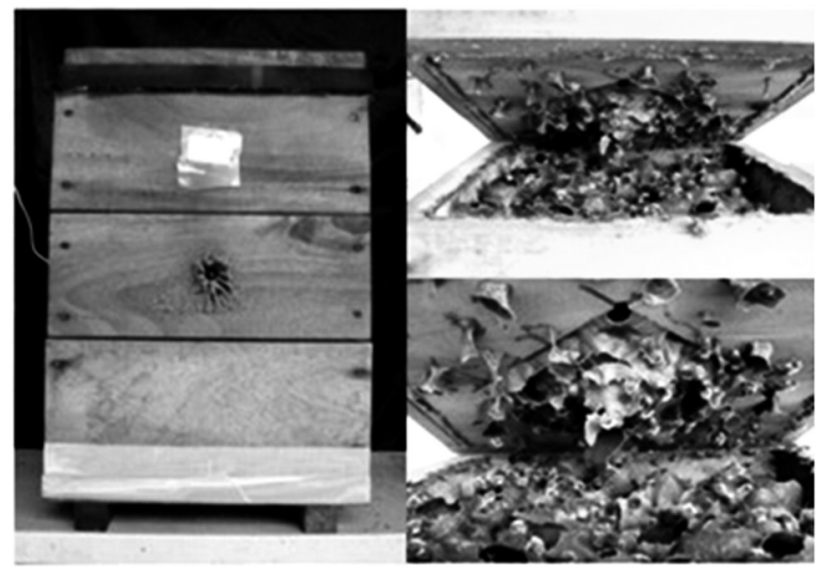

Figure 1 - Colony division of Melipona scutellaris inhabiting a managed hive. State of Bahia, Brazil.

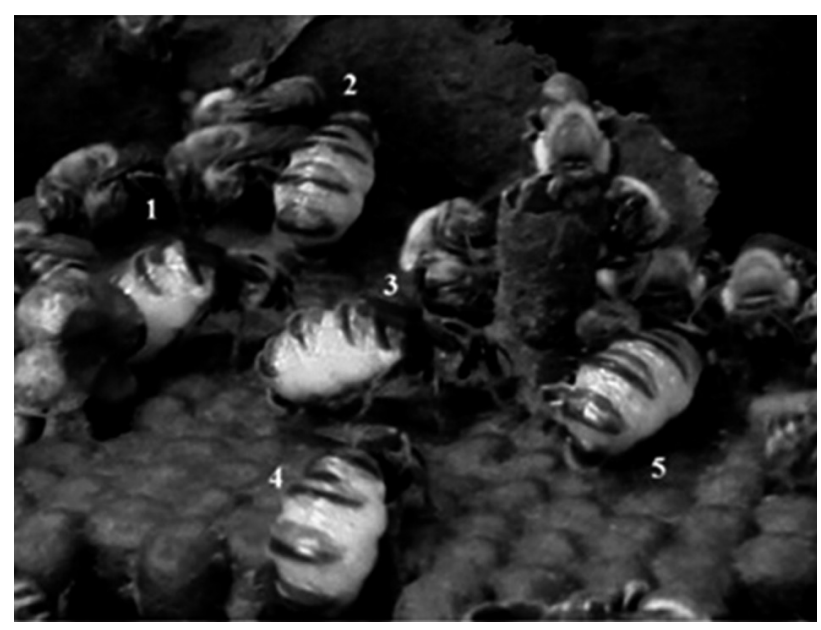

Figure 2 - Presence of five physogastric queens in a single colony of the stingless bee Melipona scutellaris. State of Bahia, Brazil.

\section{RESULTS AND DISCUSSION}

The egg-laying queens walked on the new combs and displayed no apparent aggressive behavior. The cells under construction were frequently inspected by all five queens and when the workers began provisioning cells with larval food, the queens remained around the cell. Trophic (nonviable) egg-laying by workers were immediately consumed by the queens. Egg-laying by physogastric queens, as well as interaction among the five queens, were observed even ninety days after their detection in this colony. Evidence of colony disorganization during this period was not observed. 
Carvalho-Zilse and Kerr (2004) observed that the presence of two physogastric queens of $M$. scutellaris in the same colony may ocasionally occur, when the new queen is chosen by the workers and returns from the nuptial flight, while the old queen is still present in the colony. Although the adaptive significance of polygyny remains unknown (Velthuis et al. 2006), Carvalho-Zilse and Kerr (2006) believe that it promotes genetic variability as alleles of different males are distributed in the colony. Based on microsatellite markers, these authors showed that the rate of heterozygosity observed for M. scutellaris was lower than that of Apis mellifera and both smaller than the facultative polygynic species $M$. bicolor. Therefore, both polygyny and polyandry (multiple mating), found in M. scutellaris by Carvalho (2001), may be strategies for maintaining populations of stingless bees, which are limited to short distances for mating (Carvalho-Zilse and Kerr 2004; Carvalho-Zilse et al. 2009; Francini 2009). This and other issues such as colony behavior, interaction and hierarchy among the queens, and Provision Oviposition Process (POP), can be addressed from studies of the colony following this first report of natural polygyny in $M$. scutellaris.

\section{ACKNOWLEDGMENTS}

We thank CNPq (National Research Council of Brazil) for the financial support. We also thank Ph.D. Jorge Teodoro de Souza from the Universidade Federal do Recôncavo da Bahia for the English translation and paper review.

\section{LITERATURE CITED}

Bego, L.R. 1983. On some aspects of bionomics in Melipona bicolor bicolor Lepeletier (Hymenoptera, Apidae, Meliponinae). Revista Brasileira de Entomologia, 27: 211-224.

Camargo, J.M.F.; Pedro, S.R.M. 2008. Meliponini Lepeletier, 1836. In Moure, J.S.; Urban, D.; Melo, G.A.R. (Orgs). Catalogue of Bees (Hymenoptera, Apoidea) in the Neotropical Region - online version. Available at http://www.moure.cria.org.br/catalogue. Accessed Jan/14/2010.

Cappas-e-Souza, J.P. 2000. The polygyny in Meliponine. Anais do IV Encontro sobre Abelhas: 279 (in Portuguese).

Carvalho, G.A. 2001. The Number of Sex Alleles (CSD) in a Bee Population and its Pratical Importance (Hymenoptera: Apidae). Journal of Hymenoptera Research, 10: 10-15.

Carvalho, C.A.L.; Alves, R.M.O.; Souza, B.A. 2003. Stingless bee beekeeping: practical aspects. SEAGRI, Cruz das Almas (in Portuguese).

Carvalho-Zilse, G.A.; Kerr, W.E. 2004. Natural substitutions of queens and flight distance of males in tiuba (Melipona compressipes fasciculata Smith, 1854) and uruçu (Melipona scutellaris Latreille, 1811) (Apidae, Meliponini). Acta Amazonica, 34: 649-652 (in Portuguese).
Carvalho-Zilse, G.A.; Kerr, W.E. 2006. Utilization of microsatelites markers for populations studies in Melipona scutellaris (Apidae, Meliponini). Magistra, 18: 213-220 (in Portuguese).

Carvalho-Zilse, G.A.; Costa-Pinto, M.F.F.; Nunes-Silva, C.G.; Kerr, W.E. 2009. Does beekeeping reduce genetic variability in Melipona scutellaris (Apidae, Meliponini)?. Genetics and Molecular Research (Online), 8: 758-765.

Cortopassi-Laurino, M.; Imperatriz-Fonseca, V.L.; Roubik, D.W.; Dollin, A.; Heard, T.; Aguilar, I.; Venturieri, G.C.; Eardley, C.; Nogueira-Neto, P. 2006. Global meliponiculture: challenges and opportunities. Apidologie, 37: 275-292

Francini, I.B. 2009. Genetic variability in the csd locus in captive populations of Melipona interrupta manaosensis Schwarz, 1932 and Melipona seminigra merrillae Cockerell, 1919 (Apidae, Meliponini) in the Amazon region. Msc. Thesis, Instituto Nacional de Pesquisa da Amazônia, Manaus, Amazonas. 93f (in Portuguese).

Koedam, D.; Cepeda Aponte, O.I.; Imperatriz-Fonseca, V.L. 2007. Egg laying and oophagy by reproductive workers in the polygynous stingless bee Melipona bicolor (Hymenoptera, Meliponini). Apidologie, 38: 55-66.

Michener, C.D. 1974. The Social Behavior of the Bees. Belknap Press, Harvard University Press, Cambridge, 418 pp.

Michener, C.D. 2007. The Bees of the World, $2^{\text {nd }}$ Ed. The Johns Hopins University Press, Baltimore, 953 pp.

Peters, J.M.; Queller, D.C.; Imperatriz-Fonseca, V.L.; Roubik, D.W.; Strassmann, J.E. 1999. Mate number, kin selection and social conflicts in stingless bees and honeybees. Proceedings of the Royal Society of London, 266: 379-384.

Silva, D.L.N. 1972. Considerations regarding a case of queen replacement in Plebeia (Plebeia) droryana (Friese, 1900) (Hymenoptera, Apidae). In: Tribute to W. E. Kerr, Rio Claro, SP, Brasil, 267-273 (in Portuguese).

Silveira, F.A.; Melo, G.A.R.; Almeida, E.A.B. 2002. Brazilian bees, Systematics and Identification. Fundação Acangaú, Belo Horizonte, 253 pp (in Portuguese).

Velthuis, H.H.W.; Roeling, A.; Imperatriz-Fonseca, V.L. 2001. Repartition of reproduction among queens in the polygynous stingless bee Melipona bicolor. Proceedings of the Section Experimental and Applied Entomology of the Netherlands Entomological Society, 12: 45-49.

Velthuis, H.H.W.; Vries, H. De; Imperatriz-Fonseca, V.L. 2006. The polygyny of Melipona bicolor: scramble competition among queens. Apidologie, 37: 222-239.

Witter, S.; Wittmann, D. 1997. Temporary polygyny in Plebeia wittmann Moure and Camargo, 1989 (Hymenoptera, Apidae, Meliponinae). Biociências, 5: 61-69 (in Portuguese).

Recebido em: 12/11/2009

Aceito em: 01/03/2010 
